\title{
Liquidity Positioning and Firm Performance in Industrial/Domestic Product Companies: Evidence from Nigeria
}

\author{
Anastasia Nwakaego Duru ${ }^{1}$; Michael Chidiebere Ekwe ${ }^{2}$; Grace Chinyere Eje ${ }^{3}$ \\ ${ }^{I}$ Department of Accounting, Enugu State University of Science and Technology, Enugu, Enugu State of Nigeria \\ ${ }^{2}$ Department of Accounting, Michael Okpara University of Agriculture, Umudike, Abia State of Nigeria \\ ${ }^{3}$ Enugu State University of Science and Technology, Enugu, Enugu State of Nigeria
}

\begin{abstract}
This study analyses the effect of liquidity positioning on performance of the Industrial/Domestic products manufacturing companies in Nigeria. It appraises the liquidity level expected for effective organizational performance. The variables studied included: liquidity ratio, sales growth rate and debt ratio selected for this study for the period 2000-2011. The hypotheses were analyzed and tested with the use of Generalized multiple regressions. The findings of the study show that, liquidity positioning had negative and significant relationship with industries profitability. This result is very robust as it confirms the long existing theory that idle funds yields no profits. On the other hand, sales growth rate had positive and non-significant relationship with profitability, while debt ratio had negative and non-significant relationship with profitability of industrial Domestic products manufacturing companies in Nigeria.
\end{abstract}

Key Words: Liquidity Positioning, Corporate Profitability, Industrial Product Firms, Nigeria

\section{Introduction}

When a business does not manage its liquidity well, it will have cash shortages and will result in difficulty in meeting its financial obligations. Liquidity positioning is necessary for all businesses be it small or large, which means that cash has to be collected from customers so that there will be no difficulty in paying short-term debts. Firms that have low liquidity of working capital face high risk and higher profit. The issue in managing liquidity firms must take into consideration all the items in both accounts and try to balance the risk and return. Bhunia (2007) and singh et al (2008) in their studies revealed that firms with adequate liquidity related to operational size have performed better than firms which have less liquidity in relation with their operational size Singh (2004) stated that the liquidity position of any firm mainly depends upon accounts receivable collection and payable deferred policy as well Ejelly (2004) in his own study elucidated that efficient liquidity positioning involves planning and controlling current assets and current liabilities in such a manner that eliminate the inability to meet short-term obligations. Nigeria is used in this study because of corporate failures prevailing in the country. Few Nigerian wrote on this topic and this fills the research gap. A population of all the manufacturing companies in Nigeria is used while the sample size is companies under industrial and domestic product quoted on the Nigeria Stock Exchange (NSE) for the period 2000-2011, the study aims at examining the effect of liquidity as a measure to profitability in Industrial and Domestic products manufacturing in Nigeria.

\section{Statement of Research Problem}

Some Nigerian firms have thrown out their workers forcefully into unemployment market, example Ajaokute steel complex reduced their staff from 5000 to 1000 in 2007, some manufacturing firms cannot divided to their shareholders even when they are still in Business and are also listed in the Nigeria stock Exchange champion breweries has not paid dividend since 1988, and golden, breweries has not paid theirs since 1997. It is on this background that the Researcher deemed it necessary to study the effect of liquidity on the profitability of industrial and domestic products manufacturing companies in Nigeria.

\section{Objectives of the Study}

The general objective of this study is to examine the effect of liquidity on the profitability of Industrial and Domestic manufacturing firms in Nigeria. The specific objectives are as follows:

1. To examine the effect of liquidity ratio on corporate profitability.

2. To identify the effect of debt ratio on the profitability of industrial and domestic companies in Nigeria.

3. To examine the effect of sales growth rate on corporate profitability. 


\section{Hypotheses}

The following hypotheses shall be proved in order to address the above objectives.

1. There is no significant and positive relationship between liquidity ratio and profitability of industrial and Domestic manufacturing firms in Nigeria

2. There is no significant and positive relationship between debt ratio and profitability.

3. There is no significant and positive relationship between sales growth rate and profitability.

\section{Review of Related Literature}

Ejelly, (2004), elucidated that efficient liquidity positioning involves planning and controlling current Assets and current liabilities in such a manner that eliminates the risk of inability to meet short - term obligation and avoids excision investment in these assets. He goes on to examine the relationship between profitability and liquidity and was measured by current ratio and cash gap on a sample of joint stock companies in Saudi Arabia, using correlation and regression analysis. The study found out that cash conversion cycle was more important as a measure of liquidity than current ration that affect profitability. The size variable was found to have significant effect on profitability at the industry level. The results were stable, and have important implication for liquidity positioning in various Saudi Arabia companies. First it was clear that there was a negative relationship between profitability and liquidity indicator such as current ration and cash gap in Saudi sample examined. Secondly, the study also revealed that there was a great variation among industries with respect to the significant measure of liquidity.

Enyi, (2005), studied the relative solvency level of 25 sample firms. The finding of the study revealed that the gap created by the ability of traditional liquidity measurement of solvency level like current ratio, quick ratio and other solvency ratio effectively determine the proper size or volume of working capital fulfilled by the relative solvency level model.

Mehar, (2001), studied the impact of equity financing an liquidity of 225 firms listed in Karachi stock exchange for the period 1980-1994 by using a pooled data. The finding of the study depicted that equity financing plays an important role in determining the liquidity position of firms.

Bhunia, (2007), studied liquidity positioning of public sector iron and steel enterprises in India. He found out that out that the values of working capital lowers the estimated value of working capital for both companies under study, and poor liquidity position in case of both companies.

Sing, (2004), states in his study that liquidity position of any firm mainly depends upon accounts receivable deferred policy as well as inventories conversion period of firms.

Mukhopadhyay, (2004), states that firms are badly constrained to smoothly run the day-to-day operation if there is negative working capital and also difficult to settle short term obligation..

Hutchison, (2002), examines corporate liquidity from two dimensions: static view and Dynamic view. Static view is based on commonly used traditional ratios, such as current ratio and quick ratio, calculated from balance sheet amount, which measures liquidity at a given point in time, whereas Dynamic view measures on going liquidity from the firms' operations. As a dynamic measure of the time, it takes a firm to go from cash outflow to cash conversion cycle.

Olugbenga, (2010). In his comparative study in Nigeria found out that most Nigerian companies suffer from inadequacy of liquid assets to meet their short - term financial obligations. He recommended that companies should strive to maintain optional level: short - term bank facilities should be the last resort.

Smith and Begemann (1997) emphasizes that those who promoted working capital theory shared that profitability and liquidity comprised the salient goals of working capital management. The problem arose because the maximization of the firm's returns could seriously threaten its liquidity, and the pursuit of liquidity had a tendency to dilute returns. This article evaluated the association between traditional and alternative working capital measure and return on investment (ROI) specifically in industrial firms listed on the Johannesburg stock Exchange (JES). The problem under investigation was to establish whether the more recently developed alternative working capital concepts showed improved association with return on investment to that of traditional working ratios or not. Results indicated that there were no significant differences amongst the years with respect to the independent variability in return on investment (ROI). The statistical test results showed that a traditional working capital leverage ratio, current liabilities divided by funds flow, displayed the greatest associations with return on investment well - know liquidity concepts such as the current and quick ratios registered insignificant associations while only on the newer working capital concepts, the comprehensive liquidity the comprehensive liquidity index, indicated significant associations with return on investment.

In the study of Yeboah and Kwaku (2010) It was found out that cash position of banks, creditors payment period and profitability have significantly positive relationship, with the cash position of bank in Ghana 


\section{Research Design}

\section{Methodology}

The ex-post factor research design was used, because this study involves the events that have already taken place in the past. The records that were observed were from 2000 to 2011, a period of twelve years.

\section{Population and Sample Size}

The population of this study is firms all manufacturing firms in Nigeria. The sample size consists of only companies in industrial/Domestic products. The choice of this sub-sector was due to the fact the country has high labour in manufacturing sub-sector.

\section{Nature and Source of Data}

This study used only secondary data that were extracted from the Annual Reports and statement of accounts of the selected industrial / domestic products manufacturing firms. The data for this study include, profit before tax, total assets, current assets, current liabilities, long term debt among others.

\section{Description of Variables}

The choice of these research variables was guided by pervious empirical study along this line, and the variables are in consistent with Bhunia (2007) Enyi, (2005) and Ejelly, (2004).

\section{Dependent Variable}

The dependent variable of this study is the firm's profitability. In order to analyze the impact of liquidity positions on firms performance, Profitability ratio (the return on assets) was used as dependent variable because it is an indicator of managerial efficiency, Deloof, (203) Singh, (2009) Karaduman et al (2011) among others

Profitability $=$ PAT

\section{Total Asset}

\section{Independent Variable}

Liquidity Ratio.

Liquidity positioning is important for ongoing concern. Liquidity is ascertained by using current ratio to provide the position of a business at a particular time.

Current Ratio $=\underline{\underline{\text { Current Assets }}}$

Current Liabilities.

Sales growth rate; the sales growth rate is the increase or decrease of annual sales measured as a percentage of annual sales. In this study sales growth rate was measured as sales 1 - sales 0 divided by sales 0 .

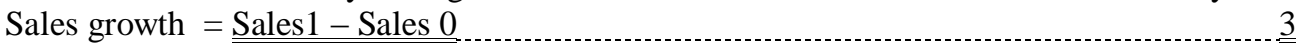

Sales 0

Debt ratio; There is an assumption that when external founds are borrowed from banks at a fixed rate that they can be invested in the company and a higher interest paid to the bank is gained. Debt ratio is measured by the long - term debt to assets.

Debt ratio $=\quad \underline{\underline{T o t a l} \text { Debt }}$

\section{Total Asset}

Technique for Test of Hypotheses

The four functional models of multiple regression were used in analyzing the computed data for the variables involved in this study. The best- fit model was selected to the analysis. The four functional models employed in the analysis include:-

a. $\quad$ Linear regression model:

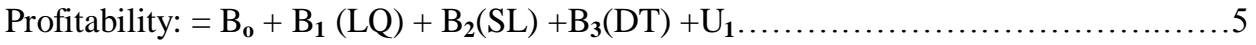

b. $\quad$ Semi $-\log$ regression Model:

Profitability: $\log \mathrm{B}_{0}+\log \mathrm{B}_{1}(\mathrm{LQ}) \log +\mathrm{B}_{2}(\mathrm{SL})+\mathrm{B}_{3}(\mathrm{DT})+\mathrm{U}_{1} \ldots \ldots \ldots \ldots \ldots \ldots \ldots \ldots$

c. $\quad$ Double log regression Model:

Profitability $=\log \mathrm{B}_{0} \log +\mathrm{B}_{1}(\mathrm{LQ})+\mathrm{B}_{2}(\mathrm{SL})+\mathrm{B}_{3}(\mathrm{DT})+\mathrm{U}_{1} \ldots \ldots \ldots \ldots \ldots \ldots \ldots \ldots \ldots 7$

d. $\quad$ Exponential regression Model:

Log profitability $\mathrm{B}_{0}+\mathrm{B}_{1}(\mathrm{LQ})+\mathrm{B}_{2}(\mathrm{SL})+\mathrm{B}_{3}(\mathrm{DT}) \ldots \ldots \ldots \ldots \ldots \ldots \ldots \ldots \ldots \ldots \ldots \ldots$

After obtaining the results of the four functional multiple regression models, decision were taken on which among them should be chosen as the best filled model in the analysis. The choice models were used in the 
interpretation of results. Decision and choice models were based on the one that has the highest number of variables.

\section{Data Presentation.}

Raw Data for Aluminum and Extrusion Company Plc.

\begin{tabular}{|c|c|c|c|c|}
\hline Years & Return on Asset Ratio & Liquidity Ratio & Debt Ratio & $\begin{array}{l}\text { Sales Growth Rate } \\
(\%)\end{array}$ \\
\hline 2000 & -0.17457 & 0.644753 & 0.132355 & 149.3861 \\
\hline 2001 & 0.027075 & 0.726668 & 0.129362 & 107.6118 \\
\hline 2003 & -0.10002 & 0.54013 & 0.158807 & 0.055333 \\
\hline 2004 & -0.00359 & 1.079555 & 0.574492 & 46.18196 \\
\hline 2005 & 0.025307 & 0.844166 & 0.489302 & 19.34508 \\
\hline 2008 & 0.132689 & 0.274149 & 0.066074 & 25.85389 \\
\hline 2009 & 0.183129 & 0.399638 & 0.022846 & 15.72687 \\
\hline 2010 & 0.107863 & 0.534355 & 0.030635 & 6.168729 \\
\hline 2011 & 0.08267 & 0.58354 & 0.043248 & 7.461922 \\
\hline
\end{tabular}

Source: Author's Computation from Annual Accounts of Firm 2000-2011.

This company did not make enough profit especially in 2002 where they made no profit. They have up to 5.012 as their receivable ratio in 2006 and lowest of 0.002 in 2011. Their stock turnover ratio is high in 2005 but low in other years. Liquidity ratio is $84 \%$ in 2005 and $27 \%$ in 2008. They did not borrow in 2002 and 2006. Their sales growth rate is high except in 2002 and 2006.

Raw Data for BOC Cases Plc.

\begin{tabular}{lllll}
\hline Years & Return on Asset Ratio & Liquidity Ratio & Debt Ratio & Sales Growth Rate (\%) \\
\hline $\mathbf{2 0 0 0}$ & 0.189275 & 1.288734 & 0 & -65.9259 \\
$\mathbf{2 0 0 1}$ & 0.168305 & 1.317834 & 0 & 23.40414 \\
$\mathbf{2 0 0 2}$ & 0.22658 & 1.326488 & 0 & 16.84696 \\
$\mathbf{2 0 0 3}$ & 0.204921 & 1.27238 & 0 & 5.95848 \\
$\mathbf{2 0 0 4}$ & 0.105303 & 0.645921 & 0.026881 & 11.35017 \\
$\mathbf{2 0 0 5}$ & 0.070344 & 0.699019 & 0.021972 & 12.39635 \\
$\mathbf{2 0 0 6}$ & 0.114355 & 2.160556 & 0 & 16.88493 \\
$\mathbf{2 0 0 7}$ & 0.148103 & 2.276143 & 0.021285 & 41.95916 \\
$\mathbf{2 0 0 8}$ & 1.608196 & 2.340526 & 0 & 7.075497 \\
$\mathbf{2 0 0 9}$ & 2.137864 & 2.314747 & 0 & -88.9498 \\
$\mathbf{2 0 1 0}$ & 0.244451 & 1.453875 & 0 & 944.6215 \\
$\mathbf{2 0 1 1}$ & 0.230765 & 1.723196 & 0 & 2.030441 \\
\hline
\end{tabular}

Source: Author's Computation from Annual Accounts of Firm 2000-2011.

BOC Cases Plc did well in 2009 because it made more profit than in other years it did not do well. The liquidity ratio was encouraging in 2006, 2007,2008 and 2009 respectively, their lowest liquidity ratio is 0.645 , they borrowed only in 2004, 2005 and 2007, but did not borrow in other years.

Raw Data for First Aluminum Plc.

\begin{tabular}{lllll}
\hline Years & Return on Asset Ratio & Liquidity Ratio & Debt Ratio & Sales Growth Rate (\%) \\
\hline $\mathbf{2 0 0 0}$ & 0.034205 & 1.138943 & 0.017556 & 37.45874 \\
$\mathbf{2 0 0 1}$ & -0.05427 & 0.857254 & 0.097599 & 21.64458 \\
$\mathbf{2 0 0 2}$ & -0.07504 & 0.743331 & 0.037068 & 3.929083 \\
$\mathbf{2 0 0 3}$ & 0.060228 & 0.986241 & 0 & 17.73386 \\
$\mathbf{2 0 0 4}$ & 0.029809 & 0.943693 & 0.067587 & 32.34261 \\
$\mathbf{2 0 0 5}$ & 0.039676 & 0.968488 & 0.038525 & 26.70396 \\
$\mathbf{2 0 0 6}$ & 0.00423 & 0.931358 & 0.035696 & -89.3193 \\
$\mathbf{2 0 0 7}$ & 0.013302 & 1.144051 & 0.032279 & 906.843 \\
$\mathbf{2 0 0 8}$ & 0.054515 & 0.995711 & 0.023784 & -7.2634 \\
$\mathbf{2 0 0 9}$ & 0.005564 & 1.052736 & 0.02233 & 2.598037 \\
$\mathbf{2 0 1 0}$ & -0.02837 & 1.025672 & 0 & 5.675414 \\
$\mathbf{2 0 1 1}$ & -0.02823 & 1.023692 & 0 & 0.33763 \\
\hline
\end{tabular}

Source: Author's Computation from Annual Accounts of Firm 2000-2011.

This company did not make enough profit. The highest return on asset ratio is 0.034 in 2000 . Liquidity ratio is better in 2000, 2007, 20092010 and 2011 respectively. The company did not borrow in 2003, 2010 and 2011. Generally, their sales growth ratio is high. They made huge sales still they could not make enough profit. 
Liquidity Positioning and Firm Performance in Industrial/Domestic Product Companies.....

Raw Data for Nigeria Enamelware Plc.

\begin{tabular}{|l|l|l|l|l|}
\hline Years & Return on Asset Ratio & Liquidity Ratio & Debt Ratio & Sales Growth Rate (\%) \\
\hline 2000 & 0.055609 & 1.067457 & 0 & -85.3937 \\
\hline 2001 & 0.046812 & 1.07913 & 0 & 29.50315 \\
\hline 2002 & 0.044657 & 1.106424 & 0 & 0.647805 \\
\hline 2003 & 0.035341 & 0.875633 & 0 & 6.281947 \\
\hline 2004 & 0.027997 & 1.455332 & 0 & -90.7981 \\
\hline 2005 & 0.040731 & 1.196748 & 0 & 985.5856 \\
\hline 2006 & 0.037447 & 12.3837 & 0 & -11.4427 \\
\hline 2007 & 0.031938 & 1.222207 & 0 & -0.28251 \\
\hline 2008 & 0.032037 & 1.223348 & 0 & -3.75639 \\
\hline 2009 & 0.091262 & 1.164838 & 0 & 59.79402 \\
\hline 2010 & 0.087434 & 1.205792 & 0 & -2.3203 \\
\hline 2011 & 0.121361 & 1.309605 & 0 & 0.345576 \\
\hline
\end{tabular}

Source: Author's Computation from Annual Accounts of Firm 2000-2011.

The return of asset ratio of this company is low, None of the companies got up to $20 \%$ of profit. This company has liquidity ratio of more than 1.0 in all the years except in 2003 when it has 0.875 which is too low, they did not borrow at all in the years under study. The highest sales growth ratio is 985.58 in 2005 and low ratios in other years.

\section{Raw Data for Vita Foam Nigeria Plc.}

\begin{tabular}{|l|l|l|l|l|}
\hline Years & Return on Asset Ratio & Liquidity Ratio & Debt Ratio & Sales Growth Rate (\%) \\
\hline 2000 & 4.91608 & 1.259264 & 3.169866 & -2.55417 \\
\hline 2001 & 0.790495 & 1.272154 & 0.428224 & 45.97292 \\
\hline 2002 & 0.705918 & 1.267943 & 0.493476 & -88.9543 \\
\hline 2003 & 0.696921 & 1.301187 & 0.499186 & 946.024 \\
\hline 2004 & 0.267607 & 1.588526 & 0.2291 & -6.07238 \\
\hline 2005 & 0.089483 & 1.628719 & 0.170737 & -3.4377 \\
\hline 2006 & 0.125305 & 1.486494 & 0.095042 & 15.18871 \\
\hline 2007 & 0.172302 & 1.606318 & 0.088006 & 51.43039 \\
\hline 2008 & 0.089192 & 1.537045 & 0.136418 & 26.35814 \\
\hline 2009 & 0.101853 & 1.613712 & 0.070708 & 1.79639 \\
\hline 2010 & 0.134751 & 1.36147 & 0.003727 & 34.31674 \\
\hline 2011 & 0.140849 & 1.312799 & 0.006186 & 21.39204 \\
\hline
\end{tabular}

Source: Author's Computation from Annual Accounts of Firm 2000-2011.

Vita foam Plc made enough profit of 4.914 in 200,0 but little in other years. If approximated their liquidity ratio is up to 2 in 2004, 2005, 200620072008 and 2009. This implies that in these years they can be able to settle their financial obligations. They borrowed in all the years under study. The sales growth rate is high from 2006 to 2011 and also in 2001.

Raw Data for Vono Products Plc.

\begin{tabular}{|l|l|l|l|l|}
\hline Years & Return on Asset Ratio & Liquidity Ratio & Debt Ratio & Sales Growth Rate (\%) \\
\hline 2000 & 0.049152 & 1.39601 & 0 & -97.5338 \\
\hline 2001 & 0.009833 & 1.188563 & 0 & -1.62607 \\
\hline 2002 & 0.056677 & 1.178557 & 0 & 21.44706 \\
\hline 2003 & 0.06283 & 1.296213 & 0 & 15.80251 \\
\hline 2004 & -0.80435 & 0.55205 & 0 & -35.5932 \\
\hline 2005 & -0.21107 & 1.446484 & 0 & -6.63423 \\
\hline 2006 & 0.035496 & 0.56206 & 0 & 14.03441 \\
\hline 2007 & -0.48964 & 0.405234 & 0 & 365.3164 \\
\hline 2008 & -0.12629 & 0.390741 & 0 & -55.1426 \\
\hline 2009 & -0.12209 & 0.273435 & 0 & -28.894 \\
\hline 2010 & -0.18286 & 0.390633 & 0.192664 & -2.34065 \\
\hline 2011 & -0.13616 & 0.370545 & 0 & 23.37397 \\
\hline
\end{tabular}

Source: Author's Computation from Annual Accounts of Firm 2000-2011.

This company did not make profit in 2004, 2006, 2007 and2008 but made little profit in others. Liquidity ratio is better in the first four years and also in 2005, there was no borrowing in the year $2000-2011$ sales growth ratio is higher in 2007 followed by 2011, while this sales growth rate in many year are negative. 


\section{Results of Regression Analysis}

Multiple Regression Analysis showing the relationship between Profitability ratio and LQ, DT and SL of Aluminum Extrusion Nigeria PLC

\begin{tabular}{|l|l|l|l|l|}
\hline Variables & Linear Regression & Semi Log Regression & Double Log Regression & Exponential Regression \\
\hline Constant & $0.262^{* *}(4.788)$ & $-0.232 * *(-3.844)$ & $-0.036(-0.049)$ & $-1.465 * * *(-5.495)$ \\
\hline Liquidity Ratio (LQ) & $-0.244(-2.047)$ & $-0.350^{*}(-2.734)$ & $1.771(1.137)$ & $0.788(1.355)$ \\
\hline Debt Ratio (DT) (Control) & $-0.032(-0.207)$ & $-0.046(-0.371)$ & $-1.571(-1.035)$ & $1.114(1.458)$ \\
\hline $\begin{array}{l}\text { Sales Growth Rate (SL) } \\
\text { Control) }\end{array}$ & $0.001(1.389)$ & $0.059(0.815)$ & $-1.325(-1.495)$ & $-0.002(-1.058)$ \\
\hline $\mathrm{R}^{2}$ & 0.922 & & & 0.929 \\
\hline Adjusted R & 0.786 & 0.896 & -0.120 & 0.805 \\
\hline F-Ratio & $6.774 *$ & 0.714 & 0.832 & $7.482^{* *}$ \\
\hline
\end{tabular}

NB: 1.Profitability=Bo + Bi(LQ)ii + B2DT 2i + B2SL 2i + Ui

2. Also, $1 \%, 5 \%, 10 \%$ levels of significance are represented by $* * * ; * *$ and $*$ respectively

3. Values in brackets are coefficients while those outside brackets are t-values of the variables

On the other hand, the industries' AP, STO, LQ and CCC all had significant and positive relationships with the profitability ratio at $1 \%$ levels of significance. This means that unit increases in the variables shall bring about corresponding increases in the profitability ratio of the industries in Nigeria.

B.O.C CASE Multiple Regression Analysis showing the relationship between Profitability ratio and LQ, DT and SL of B.O.C Case Nigeria PLC

\begin{tabular}{|l|l|l|l|l|}
\hline Variables & Linear Regression & Semi Log Regression & Double Log Regression & Exponential Regression \\
\hline Constant & $-0.551(-1.668)$ & $0.351^{*}(2.382)$ & $-0.638^{* *}(-2.914)$ & $-1.335(-0.435)$ \\
\hline Liquidity Ratio (LQ) & $-0.405^{*}(-2.367)$ & $1.683^{* *}(3.712)$ & $1.073(1.594)$ & $-0.063(-0.039)$ \\
\hline Debt Ratio (DT) (Control) & $-9.821^{* *}(-3.064)$ & $0.176^{*}(2.271)$ & $0.195(1.702)$ & $14.032(0.471)$ \\
\hline $\begin{array}{l}\text { Sales Growth Rate (SL) } \\
\text { Control) }\end{array}$ & $0.000(1.287)$ & $0.102(1.377)$ & $0.073(0.664)$ & $0.000(0.189)$ \\
\hline $\mathrm{R}^{2}$ & 0.995 & 0.985 & 0.924 & 0.294 \\
\hline Adjusted R ${ }^{2}$ & 0.987 & 0.959 & 0.790 & -0.941 \\
\hline F-Ratio & $118.302^{* * *}$ & $37.311^{* * *}$ & $6.921 * *$ & 0.238 \\
\hline
\end{tabular}

NB: 1.Profitability=Bo + Bi(LQ)ii + B2DT $2 \mathrm{i}+\mathrm{B} 2 \mathrm{SL} 2 \mathrm{i}+\mathrm{Ui}$

2. Also, $1 \%, 5 \%, 10 \%$ levels of significance are represented by $* * * ; * *$ and $*$ respectively

3 . Values in brackets are coefficients while those outside brackets are t-values of the variables

Specifically the results showed that LQ, STO and CCC had significant negative relationships with the industries' profitability ratio at $1 \%$ level of significance. This implies that a unit increase in LQ,STO and CCC shall bring about corresponding decrease in the profitability ratio of B.O. Case Nigeria PLC.

ENAMELWARE

Multiple Regression Analysis showing the relationship between Profitability ratio and LQ, DT and SL of Enamelware Nigerian PLC

\begin{tabular}{|l|l|l|l|l|}
\hline Variables & Linear Regression & Semi Log Regression & Double Log Regression & Exponential Regression \\
\hline Constant & $0.115^{* *}(2.629)$ & $-0.022(-0.415)$ & $-1.980 * *(-6.217)$ & $-0.389(-0.533)$ \\
\hline Liquidity Ratio (LQ) & $-0.000(-0.319)$ & $0.002(0.063)$ & $0.234(0.215)$ & $0.023(0.575)$ \\
\hline Debt Ratio Rate (DT) (Control) & NA & NA & NA & NA \\
\hline Sales Growth (SL) (Control) & $-2.177 \mathrm{E}-7$ & 0.463 & 0.039 & 0.000 \\
& $(-0.008)$ & $(0.004)$ & $(0.819)$ & $(0.772)$ \\
\hline $\mathrm{R}^{2}$ & 0.704 & 0.693 & 0.765 & 0.350 \\
\hline Adjusted R & 0.349 & 0.324 & 2.709 & -0.429 \\
\hline F-Ratio & 1.983 & 1.880 & & 0.450 \\
\hline
\end{tabular}

NB: 1.Profitability=Bo + Bi(LQ)ii + B2DT $2 \mathrm{i}+$ B2SL 2i + Ui

2. Also, $1 \%, 5 \%, 10 \%$ levels of significance are represented by $* * * ; * *$ and $*$ respectively

3. Values in brackets are coefficients while those outside brackets are t-values of the variables

Specifically the results showed that AR and LQ had significant positive relationships with the company's profitability ratio at $1 \%$ level of significance. This implies that a unit increase in LQ shall bring about corresponding increase in the profitability ratio of Enamelware Nigeria PLC. 
Liquidity Positioning and Firm Performance in Industrial/Domestic Product Companies.....

\section{VTA FOAM}

Multiple Regression Analysis showing the relationship between Profitability ratio and LQ, DT and SL of Vita Foam PLC

\begin{tabular}{|l|l|l|l|l|}
\hline Variables & Linear Regression & Semi Log Regression & Double Log Regression & Exponential Regression \\
\hline Constant & $0.963(1.808)$ & $2.663(1.606)$ & $0.658(1.328)$ & $2.457^{*}(2.225)$ \\
\hline Liquidity Ratio (LQ) & $-0.646(-1.807)$ & $-20.974 *(-2.745)$ & $-0.108^{* *}(-3.550)$ & $-1.810^{*}(-2.441)$ \\
\hline Debt Ratio (DT) (Control) & $1.507 * *(32.220)$ & $0.0650(1.461)$ & 0.3840 .133 & 0.0510 .527 \\
\hline $\begin{array}{l}\text { Sales Growth Rate (SL) } \\
\text { Control) }\end{array}$ & $0.000(-0.950)$ & $-0.677(-1.813)$ & $-0.084(-0.753)$ & $0.000(-1.896)$ \\
\hline $\mathrm{R}^{2}$ & 0.998 & & & 0.951 \\
\hline Adjusted R ${ }^{2}$ & 0.995 & 0.867 & 0.922 & 0.886 \\
\hline F-Ratio & 347.90 & 0.633 & 0.786 & $11.190^{* *}$ \\
\hline
\end{tabular}

NB: 1.Profitability=Bo + Bi(LQ)ii + B2DT $2 \mathrm{i}+\mathrm{B} 2 \mathrm{SL} 2 \mathrm{i}+\mathrm{Ui}$

2. Also, $1 \%, 5 \%, 10 \%$ levels of significance are represented by $* * * ; * *$ and $*$ respectively

3. Values in brackets are coefficients while those outside brackets are t-values of the variables

Specifically the results showed that AR had significant positive relationship with the company's profitability ratio at $1 \%$ level of significance. This implies that a unit increase in the variable shall bring about corresponding increase in the profitability ratio of Vita foam PLC. On the other hand, the company's STO,AP, CCC and LQ all had significant but negative relationships with the profitability ratio at $1 \%$ levels of significance. This means that unit increases in the variables shall bring about corresponding decreases in the profitability ratio of the company in Nigeria.

Vono products

Multiple Regression Analysis showing the relationship between Profitability ratio and LQ, DT and SL of Vono Product Nigeria PLC

\begin{tabular}{|l|l|l|l|l|}
\hline Variables & Linear Regression & Semi Log Regression & Double Log Regression & Exponential Regression \\
\hline Constant & $-0.166(-1.894)$ & $-0.080(-0.662)$ & $-0.413(-0.737)$ & $0.014(0.020)$ \\
\hline Liquidity Ratio (LQ) & $0.199(1.791)$ & $0.382(1.532)$ & $-3.584 * *(-3.089)$ & $-1.405(-1.507)$ \\
\hline Debt Ratio (DT) (Control) & $0.257(0.376)$ & $0.082(0.351)$ & $-0.614-0.572$ & 1.2020 .209 \\
\hline $\begin{array}{l}\text { Sales Growth Rate (SL) } \\
\text { (Control) }\end{array}$ & $-0.001(-4.402)$ & $-0.124(-2.011)$ & $0.064(0.226)$ & $0.001(0.450)$ \\
\hline $\mathrm{R}^{2}$ & 0.924 & 0.769 & 0.789 & 0.620 \\
\hline Adjusted R ${ }^{2}$ & 0.791 & 0.365 & 0.420 & -0.045 \\
\hline F-Ratio & $6.938^{* *}$ & 1.902 & 2.140 & 0.932 \\
\hline
\end{tabular}

NB: 1.Profitability=Bo + Bi(LQ)ii + B2DT(control)2i + B2SL(control) $2 \mathrm{i}+\mathrm{Ui}$

2. Also, $1 \%, 5 \%, 10 \%$ levels of significance are represented by $* * * ; *$ and $*$ respectively

3. Values in brackets are coefficients while those outside brackets are t-values of the variables

Specifically the results showed that AR had significant negative relationship with the company's profitability ratio at $1 \%$ level of significance. This implies that a unit increase in the variables shall bring about corresponding decrease in the profitability ratio of Vono products Nigeria PLC. On the other hand, the company's LQ all had significant but positive relationships with the profitability ratio at $10 \%$ levels of significance. This means that unit increase in the variables shall bring about corresponding increase in the profitability ratio of the company's in Nigeria.

\section{Hypothesis 1}

$\mathrm{H}_{\mathrm{o}}$. There is no significant and positive relationship between liquidity ratio and profitability of industrial / Domestic products companies in Nigeria.

$\mathrm{H}_{\mathrm{i}}$ There is significant and positive relationship between liquidity ratio and profitability industrial/Domestic products companies in Nigeria.

Result show that liquidity had significant and positive relationship with of significance. This is because it had a coefficient of 3,281 and 2.2 of 0.23 profitability ratio. It means that the null hypothesis is rejected.

\section{Hypothesis 2}

$\mathrm{H}_{\mathrm{o}}$ Sales growth rate has no significant and positive relationship with profitability.

$\mathrm{H}_{\mathrm{i}}$ Sales growth rate has significant and positive relationship with profitability.

\section{Hypothesis 3}

$\mathbf{H}_{\mathbf{o}}$ There is no significant and positive relationship between debt ratio and profitability of the quoted companies under study. 
$\mathbf{H}_{\mathbf{i}}$ There is significant and positive relationship between debt ratio and profitability of the quoted companies under study.

\section{Conclusion}

In conclusion, liquidity positioning is very important in financial management. This study examined the liquidity positioning and profitability of selected quoted industrial Domestic products manufacturing companies in Nigeria. Generalized multiples regression technique was used to test the Hypotheses. It was found out that liquidity ratio had negative and significant relationship with companies' profitability. There is positive but non-significant relationship between sales growth rate and profitability, and finally it was found out that debt ratio had negative and non-significant relationship with the profitability of industrial Domestic products manufacturing companies in Nigeria.

\section{References}

[1]. Asia, and Tahmiscioglu, A. K. (1997). A Panel analysis of liquidity constraints and firm investment. Journal of American statistical association 92,455- 465 .

[2]. Bhunia, A. (2007). Liquidity positioning of public sector iron and steel enterprises in India. Vidyasager university journal of commerce. 12

[3]. Ejelly, A.M.A. (2004). Liquidity - profitability trade - off: An empirical investigation in emerging market. International journal of commerce and management. 14[2], 48-61.

[4]. Enyi, E.P. (2005). Applying relative solvency to working capital management.Kafi, kafi university press.

[5]. Hutchson P. D (2002). Cash-to-cash: The new supply chain management metric international journal of physical distribution and logistics management 32(4)

[6]. Karaduman. H.A. Akbas, H.E. caliskan, A.O. and Durers, (2011). The relationship between working capital management and profitability: evidence form and an emerging market. International research journal of finance and economics issue, $62,61-67$.

[7]. Kim, C.S. Mauer, D.L. and Sherman, (1998). The determinants of corporate liquidity. Theory and Evidence Journal financial and quantitative analysis 33 (3).

[8]. Mehar,D. (2001). Impact of equity financial on position of firm. Applied financial economics $425-438$.

[9]. Mukhopadhay, D. (2004). Working capital management in Heavy Engineering firms. A case study - British Library Direct, 39, 317323.

[10]. Oluboyed, A. (2007). Working capital and liquid position. The Nigeria Accountant, $40,3$.

[11]. Olugbenga, J. (2010). An Appraisal of the relationship between working capital and liquid Assets of Nigerian companies: A comparative study of then selected companies, Journal of research in National development, 8, (1),

[12]. Salandeen,L. (2001). The nation, September, 13

[13]. Sanna, L. (2009). Impact of liquidity positioning on profitability: A case study of the adaptation of liquidity strategies in a financial crises. http:// urn.kb.se/resolve.

[14]. Sharma, A.K. and Kumar S. (2011). The effect of working capital management on firm profitability: empirical evidence from India. Global business review.12[ 1], $159-173$.

[15]. Singh, (2004). Inventory and working capital management: and empirical analysis. The kafia university journal of accounting research 35 .

[16]. Smith, M.B. and Begemann, E. (1997). Measuring Association between working capital and return on investment. South Africa Journal of business management. 28, (1), 1-5.

[17]. Wachowicz, (2004). The relationship between working capital management and firm performance: evidence from Iran. International journal of Humanities and social 2 [2] (special issue).

[18]. Yeboah, B. and Kwaku, S.A. (2010). Working capital management and cash Holding of Banks in Ghana, European Journal of Business and management, 4, (13). 